\title{
The Determinants Of Preeclampsia In Pregnant Women Of Tarakan
}

\author{
Yuni Retnowati ${ }^{1}$ \\ ${ }^{1}$ Faculty of health sciences, Borneo Tarakan University, North Kalimantan, Indonesia \\ *Corresponding Author: \\ Email: yuni10retnowati@gmail.com
}

\begin{abstract}
Preeclampsia is hypertension that can affect all organs, occurs after 20 weeks of gestation, which begins with endothelial dysfunction and decreased organ perfusion often characterized by proteinuria. Preeclampsia occurs in 5-7\% of all pregnancies and is the leading cause of maternal death in the developing world. The purpose of this research was to identify risk factors associated with the incidence of preeclampsia in pregnant women at the Public health center Karang Rejo Tarakan in 2021. This research used a case-control study design. The data used secondary data from mothers medical record with preeclampsia and without preeclampsia in the period 1 July 2020 -30 June 2021. The number of samples was 60 cases and controls. Analysis of data used univariate, bivariat analysis used chi square test. Results: Bivariat analysis showed that factors associated with preeclampsia were age $>35$ years and a history of hypertension. Conclusion: The most dominant factor related to the incidence of preeclampsia in pregnant women is a history of hypertension.
\end{abstract}

Keywords: preeclampsia, maternal, age, hypertension

\section{INTRODUCTION}

Maternal Mortality Rate (MMR) is one indicator that can describe the welfare of society in a country. The World Health Organization (WHO) reveals that 830 women die from complications of pregnancy and childbirth every day and about $99 \%$ of all maternal deaths occur in developing countries. (1). The results of the 2015 Survey antar Sensus (SUPAS) show that Indonesia's maternal mortality rate is 305 per 100,000 live births and around $80 \%$ of maternal deaths are due to increased complications during pregnancy, childbirth and after delivery. (2). Maternal mortality in Indonesia is still dominated by three main causes of death, namely bleeding, Hypertension in Pregnancy in the form of preeclampsia and eclampsia, and infectious diseases. More than 25\% of maternal deaths in Indonesia in 2013 were caused by HDK. The proportion of HDK incidence in 2010 was $21.5 \%, 2011$ was $24.7 \%, 2012$ was $26.9 \%$ and again increased in 2013 by $27.1 \%(3)$.

Preeclampsia is hypertension that can affect all organs, occurs after 20 weeks of gestation, which begins with endothelial dysfunction and decreased organ perfusion often characterized by proteinuria (4). The prevalence of preeclampsia reaches $1.3 \%-6 \%$ in developed countries and $1.8 \%-18 \%$ in developing countries. The high prevalence rate makes Preeclampsia is the second leading cause of maternal and infant mortality. Sajith et al (2014) wrote, preeclampsia is responsible for 70,000 maternal deaths per year $(4,5)$.Preeclampsia is associated with various complications for both mother and fetus, namely premature birth, impaired fetal growth, fetal death in utero, HELLP syndrome, pulmonary edema, placental abruption and maternal death. (6). In 2019, preeclampsia became the main cause of maternal mortality in the city of Tarakan, therefore researchers are interested in conducting an assessment of the determinant factors associated with the incidence of preeclampsia in the city of Tarakan.

\section{METHODS}

This study is an analytic observational study with a case-control research design. The population used in this study refers to the inclusion and exclusion criteria. The inclusion criteria for the case group were preeclamptic pregnant women who underwent pregnancy check-ups at the Karang Rejo Health Center and the 
control group, namely pregnant women who carried out pregnancy checks at the Karang Rejo Health Center without complications of preeclampsia from July 1, 2020 to June 30, 2021. The exclusion criteria in this study were mothers. pregnant women who did a pregnancy check-up at the Karang Rejo Health Center with incomplete medical records. The sample used in this study amounted to 60 samples using simple random sampling technique. The type of data used in this study is secondary data in the form of patient medical records at the Karang Rejo Health Center. The data obtained are then processed using computerization. The analysis carried out is univariate analysis and bivariate analysis, namely Chi-Square analysis.

\section{RESULTS AND DISCUSSION}

The study was conducted on July 1 2020, to June 30, 2021 at Karang Rejo Health Center there were 60 respondents. The research results are presented as follows:

\begin{tabular}{|c|c|c|c|c|c|c|}
\hline \multirow{2}{*}{ Variabel } & \multicolumn{2}{|c|}{ Case } & \multicolumn{2}{|c|}{ control } & \multicolumn{2}{|c|}{ Total } \\
\hline & $\mathbf{n}$ & $\%$ & $\mathbf{n}$ & $\%$ & $\mathrm{n}$ & $\%$ \\
\hline \multicolumn{7}{|l|}{ Umur } \\
\hline$<20$ & 2 & 6.67 & 5 & 16.6 & 7 & 11.6 \\
\hline $20-35$ & 14 & 46.67 & 22 & 73.3 & 46 & 76.67 \\
\hline$>35$ & 14 & 46.67 & 3 & 10 & 7 & 11.67 \\
\hline \multicolumn{7}{|l|}{ Paritas } \\
\hline Primigravida & 6 & 20 & 11 & 36.67 & 17 & 28.3 \\
\hline Multigravida & 24 & 80 & 19 & 63.33 & 43 & 71.67 \\
\hline \multicolumn{7}{|l|}{ Usia Gestasi } \\
\hline Trimester I & & 0 & 5 & 16.67 & 5 & 8.3 \\
\hline Trimester II & 17 & 56.67 & 9 & 30 & 26 & 43.3 \\
\hline Trimester III & 13 & 43.33 & 16 & 53.33 & 29 & 48.3 \\
\hline \multicolumn{7}{|l|}{ Gemeli } \\
\hline $\mathrm{Ya}$ & 2 & 6.67 & 0 & 0 & 2 & 3.3 \\
\hline Tidak & 28 & 93.3 & 30 & 100 & 58 & 48.3 \\
\hline \multicolumn{7}{|l|}{ Riwayat Abortus } \\
\hline $\mathrm{Ya}$ & 3 & 10 & 1 & 3.33 & 4 & 6.67 \\
\hline Tidak & 27 & 90 & 29 & 96.67 & 56 & 93.3 \\
\hline \multicolumn{7}{|l|}{ Riwayat DM } \\
\hline $\mathrm{Ya}$ & 2 & 6.67 & 1 & 3.33 & 3 & 5 \\
\hline Tidak & 28 & 93.3 & 29 & 96.67 & 57 & 95 \\
\hline \multicolumn{7}{|l|}{ Riwayat Hipertensi } \\
\hline Ya & 6 & 20 & 2 & 6.67 & 8 & 13.3 \\
\hline Tidak & 24 & 80 & 28 & 93.3 & 52 & 86.67 \\
\hline
\end{tabular}

The highest maternal age at Karang Rejo Health Center in January-June 2021 was in the age range of 20-35 years, which was $76.6 \%$. As many as $71.6 \%$ are mothers with multigravida parity, $48.3 \%$ of them have third trimester gestational age. Only 3.3\% among mothers with twins. Based on the history of the disease suffered by the mother, $6.6 \%$ of the mothers had a history of abortion, $5 \%$ of the mothers had a history of diabetes mellitus and $13.3 \%$ of the mothers had hypertension.

\begin{tabular}{|c|c|c|c|c|c|c|c|}
\hline \multirow{2}{*}{ Variabel } & \multicolumn{2}{|c|}{ Kasus } & \multicolumn{2}{|c|}{ Kontrol } & \multicolumn{2}{|c|}{ Total } & \multirow[b]{2}{*}{ p value } \\
\hline & $\mathbf{n}$ & $\%$ & $\mathrm{n}$ & $\%$ & $\mathrm{n}$ & $\%$ & \\
\hline \multicolumn{8}{|l|}{ Umur } \\
\hline$<20$ & 2 & 6.67 & 5 & 16.6 & 7 & 11.6 & \multirow{3}{*}{0.001} \\
\hline $20-35$ & 14 & 46.67 & 22 & 73.3 & 46 & 76.67 & \\
\hline$>35$ & 14 & 46.67 & 3 & 10 & 7 & 11.67 & \\
\hline \multicolumn{8}{|l|}{ Paritas } \\
\hline Primigravida & 6 & 20 & 11 & 36.67 & 17 & 28.3 & \multirow[t]{2}{*}{0.172} \\
\hline Multigravida & 24 & 80 & 19 & 63.33 & 43 & 71.67 & \\
\hline \multicolumn{8}{|l|}{ Usia Gestasi } \\
\hline Trimester I & & 0 & 5 & 16.67 & 5 & 8.3 & \multirow[t]{3}{*}{0.331} \\
\hline Trimester II & 17 & 56.67 & 9 & 30 & 26 & 43.3 & \\
\hline Trimester III & 13 & 43.33 & 16 & 53.33 & 29 & 48.3 & \\
\hline
\end{tabular}




\begin{tabular}{cccccccc}
\hline Gemeli & 2 & 6.67 & 0 & 0 & 2 & 3.3 & 0.994 \\
Ya & 28 & 93.3 & 30 & 100 & 58 & 48.3 & \\
Tidak & 3 & 10 & 1 & 3.33 & 4 & 6.67 & 0.411 \\
\hline Riwayat Abortus & & & & & & \\
Ya & 27 & 90 & 29 & 96.67 & 56 & 93.3 & 0.177 \\
Tidak & 2 & 6.67 & 1 & 3.33 & 3 & 5 & \\
\hline Riwayat DM & 28 & 93.3 & 29 & 96.67 & 57 & 95 & 0.002 \\
Ya & 6 & 20 & 2 & 6.67 & 8 & 13.3 & \\
Tidak & 24 & 80 & 28 & 93.3 & 52 & 86.67 & \\
\hline Riwayat Hipertensi & & & & \\
Ya & & & & & \\
Tidak & & & & & & \\
\end{tabular}

Maternal age and history of hypertension were statistically significantly associated with the incidence of preeclampsia. Parity, gestational spacing, gestational age, multiple pregnancies, history of abortion, history of diabetes mellitus were not statistically associated with the incidence of preeclampsia (Table 2).

\section{Discussion}

The results of this study indicate that maternal age has an effect on the incidence of preeclampsia. Duckitt reported a nearly twofold increased risk of preeclampsia in pregnant women aged 40 years or older in both primiparas and multiparas. Young age does not significantly increase the risk of preeclampsia. Robillard et al reported that the risk of preeclampsia in the second pregnancy increases with maternal age (7). At the age of more than 35 years, a degenerative process occurs which results in structural and functional changes that occur in peripheral blood vessels that are responsible for changes in blood pressure. (8). Pregnant women who are more than 35 years old, their bodies are undergoing a process of calcification. This situation will affect the circulation of food to the fetus, which in turn will affect the health of the fetus (9).History of hypertension has a significant influence on the incidence of preeclampsia. This study shows that pregnant women who have a history of hypertension are at risk for developing preeclampsia compared to women who do not have a history of hypertension.

According to Duckit the risk increases up to 7 times. Pregnancy in women with a previous history of preeclampsia is associated with a higher incidence of severe preeclampsia, early onset preeclampsia, and adverse perinatal outcomes. (7). Hypertension is caused by vasospasm (narrowing of blood vessels). Vasospasm itself can cause damage to blood vessels. These changes will lead to endothelial damage and leakage in subendothelial cells leading to blood constituents, including platelets and sub-endothelial fibrinogen deposits. $(4,10)$. The results of this study indicate that parity has no effect on the incidence of preeclampsia. This is in line with previous studies which stated that there was no relationship between maternal parity and the incidence of preeclampsia. The results of this study explain that mothers with multigravida parity have more incidences of preeclampsia than mothers with primigravida parity. The high number of cases in the multigravida group was caused by mothers with multigravida parity who had pregnancies that were too close or too far apart (71.8\%) so they had a risk of developing preeclampsia. (3). The results of this study indicate that gestational age does not affect the incidence of preeclampsia. These results are similar to previous studies which revealed that pregnant women with gestational age 37 weeks had no risk of developing preeclampsia. (3). Twin pregnancies did not have a significant effect on the incidence of preeclampsia. These results are not similar to previous studies. Sibai et al concluded that multiple pregnancies have a higher risk of developing preeclampsia than normal pregnancies $(7,11)$.

The results of the analysis showed that the history of abortion had no effect on the incidence of preeclampsia. This result is in line with previous research which states that there is no effect between a history of abortion and the incidence of preeclampsia because mothers who have a history of abortion in previous pregnancies tend to pay attention to the health condition of themselves and the fetus they contain by carrying out antenatal care to health services. $(3,7)$. The results of this study also revealed that a history of diabetes mellitus had no effect on the incidence of preeclampsia. These results are different from previous studies which revealed 
that mothers with a history of diabetes mellitus were at risk for developing preeclampsia compared to those without a history of diabetes mellitus (12). Congenital diabetes or diabetes that is acquired during pregnancy can have a negative effect on pregnancy, namely hydramnios (too much amniotic fluid), dystocia (lack of labor), and preeclampsia. This result is different because pregnant women who suffer from diabetes mellitus tend to pay more attention to their health conditions. This is due to the experience in controlling the pattern of life so that the mother's body and the fetus remain healthy $(13,14)$.

\section{CONCLUSION}

The results of this study indicate that the risk factors associated with the incidence of preeclampsia in pregnant women at the Karang Rejo Health Center are maternal age $>35$ years, obesity and a history of hypertension. The most dominant variable associated with the incidence of preeclampsia is a history of maternal hypertension.

\section{ACKNOWLEDGEMENTS}

The researchers would like thank to all parties involved in this research. This research was funded by a grant from the Institute for Research and Community Service at the University of Borneo Tarakan.

\section{REFERENCES}

[1] RI K. profil Kemenkes RI. Kementerian Kesehatan RI. 2018.

[2] Pusdatin Kemenkes RI 2017. Pusdatin Kemenkes. J Chem Inf Model. 2017;

[3] Gustri Y, Sitorus RJ, Utama F. DETERMINAN KEJADIAN PREEKLAMPSIA PADA IBU HAMIL DI RSUP DR . MOHAMMAD HOESIN PALEMBANG. J Ilmu Kesehat Masyarakatt. 2016;

[4] Sabrin G, Sunardi W, Noviyanti NI. Hubungan Kadar Soluble FMS-Like Tyrosine Kinase 1 (sFlt-1) Ibu Preeklampsia Dengan Berat Badan Lahir Bayi. J Issues Midwifery. 2020;

[5] Seyom E, Abera M, Tesfaye M, Fentahun N. Maternal and fetal outcome of pregnancy related hypertension in Mettu Karl Referral Hospital, Ethiopia. J Ovarian Res. 2015;8(1).

[6] Rana S, Lemoine E, Granger J, Karumanchi SA. Preeclampsia: Pathophysiology, Challenges, and Perspectives. Circ Res. 2019;

[7] POGI. PNPK Diagnosis dan Tatalaksana Preeklampsia. 2016;1-48.

[8] Denantika O, Serudji J, Revilla G. Hubungan Status Gravida dan Usia Ibu terhadap Kejadian Preeklampsia di RSUP Dr. M. Djamil Padang Tahun 2012-2013. J Kesehat Andalas. 2015;

[9] Prawirohardjo S. Ilmu kebidanan edisi keempat. PT Bina Pustaka Sarwono Prawirohardjo, Jakarta. 2014;

[10] Roberts JM, Druzin M, August PA, Gaiser RR, Bakris G, Granger JP, et al. ACOG Guidelines: Hypertension in pregnancy. American College of Obstetricians and Gynecologists. 2012.

[11] Sibai BM. Preeclampsia. Contemp Ob Gyn. 2016;

[12] Uzma S, Hatcher J, Azra S, Nadeem Z, Zeeshan Q, Sarah S. A multicentre matched case control study of risk factors for Preeclampsia in healthy women in Pakistan. BMC Womens Health. 2010;

[13] Rufaidah A. Faktor - faktor yang berhubungan dengan kejadian preeklampsia pada ibu hamil di rsu pku muhammadiyah bantul. Univ Aisyiyah Yogyakarta. 2018;

[14] Butar MB, A E. Faktor-faktor yang berhubungan dengan kejadian preeklampsia pada ibu hamil di RSU Royal Prima 2017. Sci J. 2018; 